\title{
Religiosity and Social Problems among Muslim Adolescents in Southern Thailand
}

\author{
Suhaimee Sateemae, M.I.S \\ (Master of Islamic Studies) \\ Lecturer in Islamic Studies \\ Islamic Studies Section \\ Satree Islam Vitaya Mulniti School \\ Yala, Thailand
}

Tarik Abdel-Monem, J.D., M.P.H.

(Juris Doctorate and Master in Public Health)

Research Specialist

University of Nebraska Public Policy Center

Lincoln, NE, U.S.A.

Corresponding author (tarik@unl.edu)

\section{Mahsoom Sateemae, M.HSc.}

(Master in Human Sciences)

Assistant Professor

Faculty of Liberal Arts and Social Sciences

Fatoni University

Pattani, Thailand

Acknowledgements: We would like to thank Satree Islam Vitaya Mulniti School and Fatoni University for their support in this research. The research findings and opinions presented in this article belong solely to the authors, and not our respective schools or institutions. Correspondence regarding this article should be directed to Tarik Abdel-Monem at tarik@unl.edu. 


\section{Abstract}

Substantial commentary has been written about the historical context of the Malay-Muslim minority in the deep south of Thailand. Much of the recent scholarship on the Malay-Muslim minority of Thailand has focused on the ongoing ethnic insurgency in southern Thailand, the region's troubled history of annexation, and its relevance to Thailand's political landscape. However, there is little empirical research on the Malay-Muslim population itself, although it is assumed that expressions of their religious identity are a fundamental aspect of collective identity formation. In an effort to fill this gap, this study explored perceptions of religiosity and risk behavior among Muslim adolescents affiliated with a private Islamic school in the province of Yala, Thailand. The study examined perceptions of this group's religious behavior and relationships to perceived social problems of concern to the community, and found that increased religious adherence mediated engagement in risk behaviors. We also found that girls were perceived to be more likely to engage in religiously adherent behavior, and less likely to engage in socially problematic behavior, than boys. This study and its findings are relevant to deepening empirical knowledge about Malay-Muslim adolescents in southern Thailand. It may also have implications for community leaders and policy makers interested in improving wellbeing among Muslim adolescents in the area.

\section{Keywords: Islam, Thailand, Southern Thailand, ponok, Religiosity}

\section{Introduction}

Muslim communities in the deep south of Thailand inhabit a unique and dynamic space. Muslims comprise approximately $5 \%$ of the total population of Thailand, but make up nearly one-third of the population in the southern region, and are the majority in the deep south (Thai National Statistics Office, 2000). The distinctiveness of contemporary Muslim communities in the area is deeply entwined with its history. The three southernmost provinces (Narathiwat, Pattani, and Yala) encompass what was once collectively known as Patani-an ethnically Malay, Islamic sultanate. Historically, Patani laid between the competing power centers of Siam to the north, and the Malayan sultanates to the south. It was far enough away from either of them to enjoy long periods of relative autonomy, but with a distinctly Malay and Islamic orientation (Virunha, 2008). Patani had developed into a prosperous sultanate with a rich tradition of Islamic scholarship before ultimately succumbing to Siamese annexation in the early $20^{\text {th }}$ century (Le Roux, 1998; Jory, 2008). But the area has always had a deeply pluralistic fabric, with overlapping Malay, Siamese, Chinese, Indian and other influences due to the historic cross-mobility that characterized the region (Koch, 1977; Reid, 2008; Suhrke, 1970; Winzeler, 1985). 
Major differentiators between these ethnically Malay Muslim communities and their Siamese counterparts are the presence of traditional Malay customs (adat) and the pervasiveness of Islamic laws (sharia) and practices (Brown, 2014). The Islamic context clearly influences all aspects of Muslim life in the southern provinces, but it is also a dynamic phenomenon. The prevalent influence of Islam in the south has changed over time, both as a result of the central government's lessening of its assimilationist policies, and a reflection of local cultural resistance to Siamese authority. The surge in global Islamic movements, influence of transnational media, philanthropy from Gulf Arab nations, and international Islamic scholarly links have all facilitated the growth of orthodox Islamic institutions in the southern provinces (Bajunid, 1999; Imtiyaz, 2009; Liow, 2010; Scupin, 1980; Yegar, 2002).

At the same time, these Muslim communities have also processed the same secular and modernizing influences that have transformed all aspects of Thai society. Thailand's integration into the global economy has been characterized by rapid industrialization and the development of export industries, and major strides in social and human development. The migration of young people from rural to urban areas in search of employment have driven internal migration, urbanization, and the dispersion of family members (Hussey, 1993; Phananiramai, 1997; Vichit-Vadakan, 1994), leading to the development of entirely new commercial sectors and urban classes. As Thailand continues to develop into a post-industrial capitalist society, it is an open question to what extent its traditional institutions will remain intact in the face of mass consumerism, global cultures, and changing forms of social organization (Jones, 1994).

Additionally, the political situation in the deep south continues to impact the overall context for Malay Muslims in the southern provinces. Much anthropological commentary and historical analysis has been made in Englishlanguage scholarship about the unique cultural space inhabited by Muslims in the south since Siamese annexation (Forbes, 1982; Jory, 2007; Scupin, 1987). Scholars have noted the region's troubled history, which has included both a series of Malay-Muslim rebellions against Siamese rule and subsequent repressions during Thailand assimilationist period in the 1920s-40s (e.g., see Aphornsuvan, 2008), and the presence of Malayan Communist Party insurgents along the porous Thai-Malay border following Malaya's independence (Hack, 2009; Liow, 2004). This analysis has particularly increased since political violence in the area escalated in 2004, with a significant upsurge in separatist attacks and incidents, and the deaths of over 70 Muslim male captives at Tak Bai, who suffocated after being crammed into Thai army vehicles following a protest (Jitpromrsi \& McCargo, 2008). Commenters have examined the roles of purported insurgency groups in this upsurge in violence (Croissant, 2007; Liow, 2004), the influence of the Thai political and policy environment (Askew, 2008; Duncan, 2006; Jitpiromrsi \& Duncan, 2008; Pathmanand, 2006); percep- 
tions and relationships of residents (Jitpiromrsi \& Duncan, 2008; Saleh, 2009), and other issues. According to Thai PBS, the official estimate of insurgencyrelated deaths from January 2004 to January 2015 is 3,961 (2,610 civilians, 509 soldiers, 365 police officers, 138 teachers, 18 monks and 321 insurgents) (Thai PBS, 2015).

There are surprisingly few recent studies examining religious and social behavior at the individual level among Muslims in the contemporary south. Recent qualitative studies on aspects of Malay Muslim life have tended to focus on the nexus with the conflict in the region, such as examinations of interreligious relations and perceptions of violence (Askew, 2009; Saleh, 2009; TanMullins, 2007), or questions of national or religious identity among residents vis-à-vis the political situation (Nilson, 2012). This trend is also reflected in larger scale survey efforts in the south that have focused on policy and security issues, such as those conducted by the Asia Foundation $(2010,2013)$ or the Center for the Study of Conflict and Cultural Diversity. There is a small body of ethnographic work or commentary focusing on religious attitudes or behavior of Muslims in the area. These works suggest that collective identity formation among these Muslim communities is characterized by a general trend toward more orthodox Islam, as opposed to localized versions, though clearly the local or syncretic influences persist (Joll, 2011). This conservative identity formation reflects the influence of modern reformist Islam in the area, local ethno-nationalism and an expression of cultural resistance to the Thai state and society (Marddent, 2007a). This aligns with the growing influence of reformist and missionary Islam in the region, which has facilitated a strong sense of ethnic and religious pride among Muslim communities (Horstmann, 2007; Liow, 2010), and corresponds to the general trend of Islamic revivalism and heightened cross-boundary solidarity with other Muslim nations in ASEAN, particularly Malaysia (LukmanThaib, 2013; Mutalib, 1990). This is a significant generational shift from the prevailing practice of Islam in the area several decades ago, which were characterized by a much less orthodox approach generally (Burr, 1972, 1974; Fraser, 1960). Although a sense of place-specific adherence to Islam in the southernmost provinces is still very relevant, much of its geo-spatial significance lie in its opposition to the cultural and political influence of Bangkok, and the perceived cultural influences that conflict with Muslim values (Marddent, 2007b; Putthongchai, 2013).

One area of interest in which there is a dearth of empirical research is the ponok-or Islamic boarding school. The tradition of ponok in the area originates with the spread of Islam to Pattani, which developed a significant reputation as a center of Islamic education throughout Southeast Asia (Madmarn, 2009). The ponok have long been recognized as playing a central role in Malay life and community, historically serving as the educational modus before the advent of modern secular models. These schools have always taught basic 
principles of religious knowledge, ethics, and morality, and thus educate young Muslims in all aspects of Islam and its centrality to identity and life (Liow, 2009; Madmarn, 2003; Suhrke, 1970). They have become the preferred educational institution for many Muslims in the south, particularly in rural areas.

After decades of failed assimilationist policies toward the ponok under the dictatorship of Field Marshall Phibunsongkram, the central government of Thailand has gradually attempted to bring the ponok into a regulated system of privately run schools which offer secular subjects along with religious ones (Arphattananon, 2011; Yong, 2012). Although the exact number of ponok in the deep south are unknown, there are believed to be at least several hundred throughout the three provinces. As of 2014, the Health Systems Management Institute of Southern Thailand lists 306 registered ponok in the three provinces of Narathiwat, Pattani, and Yala (HSMI, 2014). Modern ponok typically teach religious subjects during one half of the school day (e.g., from 8 a.m. to noon), such as tawheed (unity of God), fiqh (jurisprudence), hadith (prophetic traditions), akhlak (ethics), the Qur'an, Islamic history, and the Arabic and Malay languages. The other half of the school day (e.g., 1 p.m. to 4 p.m.) is devoted to secular subjects, including math, physical and social sciences, occupational skills, arts, the Thai and English languages, and physical activities/sports. Religious subjects are typically taught in the Malay language, and secular subjects taught in Thai, although at times religious and secular subjects are taught in an integrated fashion. The student composition varies widely across the ponok, but the vast majority of schools are composed of students from the immediate or surrounding communities. More reputable ponok may attract students from across the three southern Malay-Muslim majority provinces of Thailand. Some Thai-Muslim families from other parts of the country, such as Bangkok or the northern regions, also send their children to the southern ponok, primarily for the quality of religious education and submersion in Islamic culture. The ponok are important to the socioeconomic and political environment of the south in multiple ways beyond its salience to religious education. They serve as critical educational resources for Muslim communities in the area, where profound educational disparities have been identified relative to other parts of Thailand. It is estimated that less than $2 \%$ of the Muslim population in the three southernmost provinces have completed undergraduate degrees, compared to $10 \%$ of Siamese Thais (Jitpiromsri \& Sobhonvasu, 2007). It is believed that poor education is an important factor explaining the relatively low overall human development and poverty in the area. The three southernmost provinces have poverty rates among the poorest 20 provinces in the country (UNICEF, 2004). Additionally, the ponok have become a contentious institution in the eyes of Thai authorities because of allegations that a minority of them may promote separatist, anti-government or radical views (Chongkittavorn, 2004; Liow, 2009). 
We were interested in examining the perceived religiosity of Muslim adolescents among families with children currently enrolled in a ponok in the deep south. This inquiry is motivated by several reasons. First is the absence of studies in Islamic religiosity in Thailand. Religiosity has been examined in neighboring Malaysia, in which there is a strong cultural and historical connection, but not with this population in Thailand. Previous studies among Muslim youth in Malaysian communities should be noted in this regard (Krauss et al., 2005, 2006). Secondly, we were interested in exploring whether there was an empirical basis in the amalgamation of ethnographic, news, and anecdotal commentary about Muslim communities in the deep south. Expressions of piety in religion, including within Islam, may be generally perceived as highly gendered by outsiders. Malay Muslim women in Thailand are expected to enforce ethnoreligious solidarity through their personal, familial, and public forms of religious adherence, such as donning of hijab, dressing modestly, and so on (Prachuabmoh, 1980; Tsuneda, 2009). On the contrary, young men are anecdotally perceived to be more likely to participate in traditionally un-Islamic behavior such as smoking, drug use, etc., which media commentary has linked to criminal and political violence in the region (Fuller, 2012; Johnson, 2010). Of course, engagement in antisocial behavior is considered to be un-Islamic and morally threatening to Muslims in Thailand generally. Malay Muslims in the south regularly distinguish themselves from Thai Buddhists, who are stereotypically considered to be much more likely to engage in socially problematic behavior like drinking, gambling, and casual or commercial sex (Marddent, 2007b; Putthongchai, 2013; Tsuneda, 2009). Thus, we were interested in examining the extent to which perceived religiosity was related to gender among our sample, as well as the prevalence of engagement in various behavior considered to be "un-Islamic" by the community, such as drug use, gambling, and so on. Of particular interest was examining to what extent Islamic religiosity mediated these perceived socially problematic behaviors.

\section{Methods}

A Thai-language survey was developed and distributed to parents whose children were educated in ponok in Yala province, Thailand, one of the three southern provinces with a majority Muslim population (71\%) (Office of Cultural Affairs of Yala, 2009). The survey asked a series of demographic questions about each parent (age, education level, monthly income). The survey also asked parents to jointly indicate demographic information for their adolescent children (age and gender), and information about their secular and religious education levels (preschool, primary level, secondary level, or college level). In addition, parents were asked to jointly rate their perceptions of each of their adolescent 
children's compliance with a general set of religious duties and practices, as well as their engagement in socially problematic risk behavior. Upon disagreement between parents, the response of the head of household parent was used. Six hundred surveys were distributed to parents, and a total of 186 surveys were returned (.31 response rate). The target sample size was 153 returned and completed surveys. A power analysis indicated that a minimum sample of 153 was needed for a final regression analysis with seven predictors, assuming medium effect sizes and a desired power of 0.95 . Our return rate thus satisfied this targeted sample size. After surveys were returned, 12 university students working under the supervision of the researchers entered data into spreadsheets, working in pairs to check for accuracy. The supervising researcher also spot-checked data entry for accuracy before data was exported for analysis. Analysis was done with both SPSS and STATA data analysis applications.

The religiosity questions were composed of a series of items reflecting major practice requirements among Muslims. It should be noted that Islamic religiosity scales have been developed and tested in a variety of different contexts. Several scales that blend cohesive conceptual and behavioral items have been successfully psychometrically evaluated among Muslim populations. These include scales reflecting practice and altruism dimensions (Tiliouine, Cummins, \& Davern, 2009), overall doctrinal orthodoxy and intrinsic belief systems (Ghorbani et al., 2000; Krauss et al., 2005, 2006; Ji \& Ibrahim, 2007), beliefs derived from the Qur'an and hadith (Jana-Masri \& Priester, 2007; Suhail \& Chaudhry, 2004), Islamic ethics and positive Islamic coping practices (Abu Raiya, Pargament, Mahoney \& Stein, 2008) and others, though almost all scales include a focus on central tenets of practice. However, there is no agreement among scholars about fundamental items or dimensions that compose Islamic religiosity, or for that matter other religions or religion in general; thus, religiosity scales have been developed to suit specific research objectives and contexts (Mokhlis, 2009). Our questions (listed infra) were focused on central ritualistic practice requirements (ibadat) such as prayer five times a day, as well as behavior reflecting important values that dictate interaction with family (e.g., obedience to parents) and school (e.g., attending Islamic school courses) -all questions that we believed would be understandable and salient to adolescent Muslims without being intellectually overwhelming. The religious behavior variables also included fasting during Ramadan and other holidays, obligatory prayer at the mosque for male Muslims, wearing clothes in accordance with Islamic principles, reading the Quran regularly, consuming halal food, and regularly attending Islamic classes. The questions were developed by the researchers-one of whom is a religious teacher (ustaaz) at the ponok level - in consultation with academics from a private Islamic university in the same area as the ponok. The questions were then reviewed by other ustaaz and administrators at the ponok to ensure they were appropriate for the student body re- 
spondents based on the curriculum and culture of the school, and expectations and knowledge of their parents. The risk behavior items were based around select principles of haram (forbidden) activity (e.g., use of intoxicants), but also contained items that may have been jurisprudentially permissible from an Islamic perspective (halal), but problematic from a community perspective (e.g., "addiction" to mobile phones). These questions were developed after the researchers consulted with local community members from the vicinity of the ponok. The issues identified by these community members generally mirrored those of other Malay-Muslims throughout the southern provinces, and were thus deemed to be appropriate for the study. The survey questionnaire and design were reviewed for ethical and safety considerations by a research committee at a private Islamic university, affiliated with one of the researchers. Permission for the study was also provided by the administrators of the ponok as well.

We conducted basic descriptive and correlations analysis, with a particular focus on identifying differences between genders, and associations between engagement in religious behavior and socially problematic behavior. Additionally, multivariate analysis was conducted to further examine these relationships. Factor analysis was conducted using STATA to determine if there was internal consistency among the religious behavior items as a Religious Adherence construct. Finally, regression analysis was used to determine predictive relationships between Religious Adherence, and demographic factors and socially problematic behaviors. The final regression model used gender, age, religious education, secular education, father's income, mother's income, and a number of behavior problems to predict religious adherence. There were no exposures as this was a correlational design, and no effect modifiers were used in the model tested.

\section{Results}

\section{Descriptive Analysis}

\section{Participants, Adults}

Analysis of data was completed only for those surveys in which there were both a mother and father at home, and for which surveys had valid information that adhered to instructions. A total of 164 pairs of parents returned valid surveys. The average number of children per family was $3.7(\mathrm{SD}=1.97)$. Basic demographic information from the adult participants is presented in Table 1. The average age of fathers and mothers were 45 and 43 , respectively. Average monthly income, denoted in Thai baht ( $1 \mathrm{USD}=$ approximately $31 \mathrm{THB})$, was 
higher for males (10,274 baht) than it was for females (7,727 baht). ${ }^{1}$ Average total household monthly income was 18,932 baht, lower than both the national average of 25,194 baht and provincial average of 22,843 (Thai National Statistical Office, 2013). Parents reported an average completed education level of 1.69 (fathers) and 1.66 (mothers) on a 0 to 4 scale ( $0=$ no education, $1=$ primary, $2=$ secondary, $3=$ tertiary). Among fathers, $7 \%$ had no education, $38 \%$ reported having completed a primary education, $35 \%$ secondary education, and $17 \%$ tertiary education. Among mothers, $9 \%$ had no education, $34 \%$ reported completing primary education, $39 \%$ completed secondary education, and $17 \%$ had a tertiary education.

TABLE 1. Demographic and socioeconomic characteristics of parent respondents.

\begin{tabular}{|c|c|c|c|}
\hline Variable & $\mathrm{N}$ & Mean & $S D$ \\
\hline \multicolumn{4}{|l|}{ Age } \\
\hline Father & 164 & 45.49 & 13.24 \\
\hline Mother & 164 & 42.74 & 8.75 \\
\hline Children per family & 164 & 3.7 & 1.97 \\
\hline \multicolumn{4}{|l|}{ Monthly income* } \\
\hline Father & 139 & 10274 THB / 304 USD & 12414.30 \\
\hline Mother & 139 & 7727 THB / 229 USD & 12239.72 \\
\hline Both parents & & 18933 THB / 560 USD & 23089.55 \\
\hline \multicolumn{4}{|c|}{$\begin{array}{l}\text { *Exchange rate for Thai Baht calculated by US Internal Revenue Service average exchange rate } \mathrm{f} \\
2014 .\end{array}$} \\
\hline Variable & $\mathrm{N}$ & & Valid Percent** \\
\hline $\begin{array}{l}\text { Education level } \\
\text { Father }\end{array}$ & \multicolumn{2}{|c|}{ Education level } & \\
\hline No Education & 4 & & $3 \%$ \\
\hline Primary Education & 63 & & $41 \%$ \\
\hline Secondary Education & 58 & & $38 \%$ \\
\hline Tertiary Education & 28 & & $18 \%$ \\
\hline \multicolumn{4}{|l|}{ Mother } \\
\hline No Education & 0 & & $0 \%$ \\
\hline Primary Education & 56 & & $38 \%$ \\
\hline Secondary Education & 64 & & $43 \%$ \\
\hline Tertiary Education & 28 & & $19 \%$ \\
\hline
\end{tabular}

$\star \star$ Valid percent reported for answering respondents.

1. We examined all variables to determine if they were normally distributed. As expected based on the overall income distribution in Thailand, the distribution of both father's and mother's monthly income were non-normal (age and education levels were normally distributed). This non-normality for income was not corrected. Simulation studies have shown that even with extremely non-normal data, a sample size of 40 is sufficient for producing accurate estimates of descriptive statistics (Barrett \& Goldsmith, 1976), and a sample size of 15 is adequate to provide robustness to the presence of non-normal predictors in ordinary least squares regression (Minitab, n.d.). 


\section{Participants, Adolescent Children}

Of the 164 families, information was provided on a total of 577 adolescent children, 384 girls and 193 boys (see Table 2). We examined ratings of religious behavior of the children, on a scale of 1-5 ( $1=$ Low compliance, $5=$ High compliance). A response of 5 meant that the child in question was perceived to be strongly adherent to the religious behavior, whereas a response of 1 meant very poor adherence. Generally speaking, the parents reported generally high levels of compliance with religious behavior among their children, with almost all ratings above $3 .^{2}$ One notable exception was regular prayer at the mosque, with mean compliance levels of .49 for girls, and 2.83 for boys. It should be noted that within Islam there are different gender expectations for males and females to attend the mosque for regular prayer, particularly for young girls, thus explaining that particular gender difference.

TABLE 2. Religious behavior of children

\begin{tabular}{|c|c|c|c|c|}
\hline & Girls $(n=384)$ & Boys ( $n=193)$ & $t$ & $d f$ \\
\hline Age & $16.96(\mathrm{SD}=6.24)$ & $18.54(\mathrm{SD}=8.32)$ & $2.57^{\star}$ & 577 \\
\hline Religious Education & $2.51(\mathrm{SD}=1.29)$ & $1.98(\mathrm{SD}=1.40)$ & $-4.49 \star \star$ & 575 \\
\hline Secular Education & $2.62(\mathrm{SD}=1.09)$ & $2.24(\mathrm{SD}=1.18)$ & $-3.95^{\star \star}$ & 577 \\
\hline \multicolumn{5}{|l|}{ Religious behavior } \\
\hline Prayer 5 times/day & $4.02(S D=1.17)$ & $3.50(\mathrm{SD}=1.45)$ & $-4.60^{\star \star}$ & 577 \\
\hline Fasting in Ramadan & $4.22(\mathrm{SD}=1.31)$ & $3.75(\mathrm{SD}=1.51)$ & $-3.84^{\star \star}$ & 577 \\
\hline Prayer at Mosque & $0.49(\mathrm{SD}=1.23)$ & $2.83(\mathrm{SD}=1.64)$ & $19.27^{\star \star}$ & 577 \\
\hline Obey parents & $4.12(\mathrm{SD}=0.87)$ & $3.73(\mathrm{SD}=1.12)$ & $-4.53^{\star \star}$ & 577 \\
\hline Clothing & $4.18(S D=0.92)$ & $4.08(S D=1.09)$ & -1.19 & 577 \\
\hline Reading Qur'an & $3.98(\mathrm{SD}=1.10)$ & $3.56(\mathrm{SD}=1.39)$ & $-4.00^{\star \star}$ & 577 \\
\hline Halal diet & $4.21(\mathrm{SD}=0.90)$ & $3.92(\mathrm{SD}=1.16)$ & $-3.29^{\star}$ & 576 \\
\hline Islamic courses & $4.11(S D=1.09)$ & $3.56(S D=1.41)$ & $-5.21^{\star \star}$ & 577 \\
\hline
\end{tabular}

Of note, independent sample t-tests indicated that there were significant differences between boys and girls, including in both religious and secular education levels, as well as seven of the eight religious behavior variables. Differences were significant at a level of at least $p<.01$ for all but one variable, clothing, which was not significant; $t(557)=-1.19, p=.234$. In every case, girls had a higher mean level of religious and formal education, and higher mean ratings of engagement in religious behavior. The only exception was the prayer at the mosque variable, on which boys had a higher mean.

Parents were asked to rate their adolescent children's engagement in risk

2. Religious behavior items were not normally distributed, as expected. See supra footnote 1 for required sample sizes to conduct reliable analysis. 
behavior, using a simple "yes" (engagement) or "no" (non-engagement) question format (see Table 3). The problematic behavior variables included smoking, drinking drug cocktails, any other drug use, addiction to TV dramas, gambling addiction, phone/internet addiction, driving motorcycles dangerously, truancy from school, inappropriately engaging in heterosexual relationships, being addicted to fashion, fighting with others, and inappropriately engaging in homosexual behavior. It should be noted that these variables of interest were chosen because they are generally considered by the local community to be prohibited under Islam (haram) or otherwise problematic in nature. The activity with the highest prevalence among boys was smoking at $24 \%$, and addiction to television dramas for girls (15\%). Approximately $5 \%$ of the boys were also reported to use " $4 \times 100$ " cocktails, a drink made from the juice of kratom (mitragyna speciosa) leaves-a plant with mildly psychoactive properties-that is typically mixed with cough syrup and/or soda, and is considered to be a major problem among youth in the area.

TABLE 3. Social problem behavior of children

\begin{tabular}{lccccrr}
\hline & \multicolumn{2}{c}{ Girls $(n=384)$} & \multicolumn{2}{c}{ Boys $(n=193)$} & $X^{2}$ & p value \\
\hline Smoking & Yes & \multicolumn{1}{c}{ No } & Yes & No & & \\
Drinking 4x100 cocktails & $5(1 \%)$ & $378(99 \%)$ & $46(24 \%)$ & $148(76 \%)$ & 80.23 & .00 \\
Any other drug use & $1(0.3 \%)$ & $383(1 \%)$ & $10(5 \%)$ & $184(95 \%)$ & 16.53 & .00 \\
Addiction to TV dramas & 0 & $384(100 \%)$ & $3(1.5 \%)$ & $191(98 \%)$ & 5.96 & .05 \\
Gambling addiction & $56(15 \%)$ & $328(85 \%)$ & $7(4 \%)$ & $187(96 \%)$ & 15.98 & .01 \\
Mobile phone/internet addiction & $9(2 \%)$ & $375(97 \%)$ & $14(7 \%)$ & $180(93 \%)$ & 8.0 & .01 \\
Dangerous motorcycle driving & $10(3 \%)$ & $352(92 \%)$ & $15(8 \%)$ & $179(92 \%)$ & 5.11 & .53 \\
Truancy & $1(0.3 \%)$ & $383(99 \%)$ & $6(3 \%)$ & $188(97 \%)$ & 8.64 & .02 \\
Heterosexual relationships & $16(4 \%)$ & $368(96 \%)$ & $8(4 \%)$ & $185(96 \%)$ & 2.42 & .88 \\
Fashion addiction & $20(5 \%)$ & $363(95 \%)$ & $2(1 \%)$ & $192(99 \%)$ & 6.16 & .05 \\
Fighting with others & $8(2 \%)$ & $375(98 \%)$ & $5(3 \%)$ & $189(97 \%)$ & 2.36 & .88 \\
Homosexual behavior & $5(1 \%)$ & $378(99 \%)$ & 0 & $193(100 \%)$ & 4.68 & .59 \\
\hline
\end{tabular}

Chi-square tests were run to examine differences between child genders in social problem behavior. Significant differences were found for smoking, drinking $4 \mathrm{X} 100$ cocktails, other drug use, addiction to TV dramas, gambling, dangerous motorcycle driving, truancy, and fashion addiction. This suggests gender differences in perceived risk behavior, with male children significantly more likely to engage in smoking, drinking $4 \times 100$ cocktails, other drug use, gambling, dangerous motorcycle driving, and truancy, while female children were more likely to be addicted to TV dramas and fashion. Additionally, the number of problem behaviors present per person (total problems) was tallied, ranging from 0 to up to 5 problem behaviors, with a mean of $0.5(\mathrm{SD}=0.94)$. This variable was later used in regression analysis. 


\section{Correlations}

We examined relationships between reported religious behavior with several demographic measures (see Table 4). The gender of children showed consistent correlations with religious behavior. Girls were more likely to have higher religious behavior scores than males, at significance levels of at least $p<.01$, although correlations were small. The exception was prayer at the mosque, which was moderately correlated with being male $(r=.62, p<.001)$. As expected, age of children was also positively correlated with religious behavior, as stricter religious compliance is observed after puberty. Both religious education and secular education were positively and consistently correlated with religious behavior at significance levels of at least $p<.01$, with prayer at the mosque again being an exception, likely due to the different gender expectation for this activity. Mother's income was positively correlated with two religious behavior variables: reading the Qur'an $(r=.15, p<.05)$ and consumption of halal products $(r=.20, p<.01)$.

TABLE 4. Correlations between demographics and religious behavior of children

\begin{tabular}{|c|c|c|c|c|c|c|c|}
\hline \multirow[t]{2}{*}{ Item } & \multirow[t]{2}{*}{ Mean (SD) } & \multicolumn{6}{|c|}{ Correlations } \\
\hline & & $\begin{array}{l}\text { Gender }^{\mathrm{a}} \\
(n=579)\end{array}$ & $\begin{array}{c}\text { Age } \\
(n=588)\end{array}$ & $\begin{array}{c}\text { Religious } \\
\text { Education } \\
(n=566)\end{array}$ & $\begin{array}{c}\text { Secular } \\
\text { Education } \\
(n=588)\end{array}$ & $\begin{array}{l}\text { Father's } \\
\text { Income } \\
(n=162)\end{array}$ & $\begin{array}{l}\text { Mother's } \\
\text { Income } \\
(n=164)\end{array}$ \\
\hline Prayer 5 times/day & $3.86(1.29)$ & $-.18^{\star \star \star}$ & $.42^{\star \star \star}$ & $.43^{\star * \star}$ & $.39 * \star \star$ & .05 & .10 \\
\hline Fasting in Ramadan & $4.02(1.45)$ & $-.15^{\star \star \star}$ & $.39 * \star \star$ & $.38 * \star \star$ & $.48^{\star \star \star}$ & .06 & .14 \\
\hline Prayer at Mosquet & $1.32(1.79)$ & $.62^{\star \star \star}$ & $.19^{\star \star \star}$ & -.01 & $-.12^{\star \star}$ & $-.16^{\star}$ & -.10 \\
\hline Obey parents & $4(0.98)$ & $-.18^{\star \star \star}$ & $.15^{\star \star \star}$ & 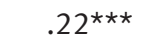 & $.16^{\star \star \star}$ & -.02 & -.08 \\
\hline Clothing & $4.16(0.98)$ & -.04 & $.18^{\star \star \star}$ & $.24^{\star \star \star}$ & $.14^{\star \star \star}$ & .01 & .07 \\
\hline Reading Qur'an & $3.85(1.21)$ & $-.16^{\star \star \star}$ & .02 & $.26^{\star \star \star}$ & $.13^{\star \star \star}$ & .04 & $.15^{\star}$ \\
\hline Halal diet & $4.12(1.00)$ & $-.13 * \star$ & .06 & $.21^{\star \star \star}$ & $.12^{\star \star}$ & .11 & $.20 * \star$ \\
\hline Islamic courses & $3.94(1.23)$ & $-.21^{\star \star \star}$ & $.10^{\star}$ & $.36^{\star \star \star}$ & $.21^{\star \star \star}$ & .14 & .08 \\
\hline
\end{tabular}

Range was $1-5$ for all religious behavior items.

aPositive correlations with Gender indicate boys were perceived as more likely to perform the behavior, while negative correlations indicate girls were more likely. Male gender was coded 1 whereas female gender coded 0 for this analysis.

${ }^{*} p<.05,{ }^{* \star} p<.01,{ }^{* \star *} p<.001$

†Different gender expectations for attendance of prayer at the mosque.

Every religious behavior characteristic was positively correlated with other religious behaviors at small or moderate levels at significance levels of at least $p<.05$ (see Table 5). The only anomaly, again, was regular prayer at the mosque. This strongly suggests that engaging in one form of religious behavior supports the likelihood of engagement in other types of religious activity.

There were several negative correlations between engagement in religious activity and problem behaviors. Most correlations were in the small range $(<.3)$. However, a clear pattern in correlations suggests that greater religious activity 
TABLE 5. Religious behavior correlation matrix

\begin{tabular}{lcccccccc}
\hline Variable & 1. & 2. & 3. & 4. & 5. & 6. & 7. & 8. \\
\hline 1. Prayer 5 times/day & - & & & & & & & \\
2. Fasting in Ramadan & $.65^{\star \star \star}$ & - & & & & & \\
3. Prayer at Mosquet & $.08^{\star}$ & $-.08^{\star}$ & - & & & & \\
4. Obey parents & $.46^{\star \star \star}$ & $.36^{\star \star \star}$ & .07 & - & & & \\
5. Clothing & $.50^{\star \star \star}$ & $.35^{\star \star \star}$ & $.13^{\star \star \star}$ & $.53^{\star \star \star}$ & - & & & \\
6. Reading Qur'an & $.54^{\star \star \star}$ & $.39^{\star \star \star}$ & .02 & $.50^{\star \star \star}$ & $.56^{\star \star \star}$ & - & & \\
7. Halal diet & $.40^{\star \star \star}$ & $.32^{\star \star \star}$ & .06 & $.57^{\star \star \star}$ & $.66^{\star \star \star}$ & $.54^{\star \star \star}$ & - & \\
8. Islamic courses & $.49^{\star \star \star}$ & $.39^{\star \star \star}$ & -.02 & $.45^{\star \star \star}$ & $.56^{\star \star \star}$ & $.70^{\star \star \star}$ & $.55^{\star \star \star}$ & - \\
\hline
\end{tabular}

${ }^{\star} p<.05,{ }^{\star \star} p<.01,{ }^{\star \star *} p<.001$

tDifferent gender expectations for attendance of prayer at the mosque.

may mitigate engagement in perceived problematic behavior. All relationships were significant at a level of at least $p<.05$, with many significant at a level of $p<.001$ (see Table 6). For example, reading the Qur'an, adhering to a halal diet, and attending Islamic courses were negatively correlated with 10 of 12 problem behaviors. Adhering to Islamic dress codes was negatively correlated with 11 problem behaviors. One noteworthy exception was a significant positive correlation between regular prayer at the mosque-the only religious behavior that is exclusively expected of male Muslims-and smoking. This seems to indicate the possibility that smoking is considered an acceptable practice among young male Muslims - a finding that would align with anecdotal observations.

TABLE 6. Correlations between religious behavior and social problem behavior of children

\begin{tabular}{|c|c|c|c|c|c|c|c|c|}
\hline \multirow[b]{2}{*}{ Item } & \multicolumn{8}{|c|}{ Correlations } \\
\hline & $\begin{array}{c}\text { Prayer } 5 \\
\text { times }\end{array}$ & Fasting & $\begin{array}{l}\text { Prayer at } \\
\text { Mosquet }\end{array}$ & $\begin{array}{l}\text { Obey } \\
\text { parents }\end{array}$ & Clothing & $\begin{array}{l}\text { Reading } \\
\text { Qur'an }\end{array}$ & $\begin{array}{l}\text { Halal } \\
\text { Diet }\end{array}$ & $\begin{array}{l}\text { Islamic } \\
\text { courses }\end{array}$ \\
\hline Smoking & -.06 & -.07 & $.23^{\star \star \star}$ & $-.18^{\star \star \star}$ & -.06 & $-.21^{\star \star \star}$ & $-.17^{\star \star \star}$ & $-.27^{\star \star \star}$ \\
\hline Drinking $4 \times 100$ cocktails & $-.15^{\star \star \star}$ & $-.08^{\star}$ & .05 & $-.19 \star \star \star$ & $-.11^{\star \star}$ & $-.20 \star \star \star$ & $-.20 * \star \star$ & $-.19 \star \star \star$ \\
\hline Any other alcohol/drug use & $-.08^{\star}$ & -.06 & .01 & $-.17^{\star \star \star}$ & -.03 & $-.17^{\star \star \star}$ & $-.20 \star \star \star$ & $-.17^{\star \star \star}$ \\
\hline Addiction to TV dramas & .01 & .06 & $-.20 \star \star \star$ & -.06 & -.02 & .02 & -.03 & .07 \\
\hline Gambling addiction & -.03 & .02 & .06 & -.02 & 0 & 0 & -.02 & -.04 \\
\hline Mobile phone/internet addiction & -.02 & -.01 & .01 & 0 & -.06 & $-.1 \star \star$ & $-.11^{\star \star}$ & $-.13^{\star \star \star}$ \\
\hline Dangerous motorcycle driving & -.05 & 0 & .06 & -.06 & $-.10^{\star \star}$ & $-.08^{\star}$ & $-.12^{\star \star}$ & $-.13^{\star \star \star}$ \\
\hline Truancy & -.04 & -.01 & .06 & $-.08^{\star}$ & $-.10^{\star}$ & $-.09^{\star}$ & $-.09^{\star}$ & $-.08^{\star}$ \\
\hline Heterosexual relationships & .01 & .05 & .02 & .02 & -.06 & -.01 & -.04 & $-.08^{\star}$ \\
\hline Fashion addiction & -.05 & -.02 & -.07 & -.02 & $-.12^{\star \star}$ & -.08 & $-.10^{\star \star}$ & -.04 \\
\hline Fighting with others & -.07 & $-.10 \star \star$ & $.08^{\star}$ & -.06 & $-.09^{\star}$ & -.06 & $-.08^{\star}$ & $-.11^{\star \star}$ \\
\hline Homosexual behavior & 0 & .05 & -.05 & .01 & -.03 & -.01 & -.06 & .03 \\
\hline
\end{tabular}

${ }^{\star} p<.05,{ }^{* *} p<.01,{ }^{* * *} p<.001$

tDifferent gender expectations for attendance of prayer at the mosque. 
Multivariate Analysis

As the religious behavior variables generally showed moderate correlations with each other, we were interested in determining if there was an internal consistency among these items. Cronbach's alpha is a coefficient of reliability used to determine the average correlation of items in a scale (Cronbach, 1951). A low alpha indicates a low average internal correlation. High reliability is indicated by an alpha score of .80 or more (Cortina, 1993; Peterson, 1994). Cronbach's alpha was determined using seven of the eight religious behavior items, with prayer at the mosque being dropped due to its inconsistencies. The seven variables had a high degree of internal consistency $(\alpha=.86)$. Factor analysis methods were used to determine the dimensionality of the items (Rogers, Schmitt, \& Mullins, 2002; Schmitt, 1996; Tavakol \& Dennick, 2011). Factor analysis is basically employed to reduce a set of variables to a smaller number of underlying constructs (Ruscio \& Roche, 2012; Sass \& Schmitt, 2010). Determining how many such constructs, or factors, exist within a set of variables is a principal function of factor analysis, and is appropriate when there are suitably strong correlations and an adequate sample size, conditions which were both met here (DeVellis, 2011). Three factors were retained by default as the remaining four had negative eigenvalues (see Table 7). A single factor had an eigenvalue of 3.56, explaining $97 \%$ of the variance. Factor loadings showing correlations between each of the seven variables and Factor 1 were consistently strong. These findings indicated the presence of a single strong underlying construct for these religious variables, or Religious Adherence. A factor score for Religious Adherence was created for later use in regression analysis.

TABLE 7. Presence of religious construct and factor loading

\begin{tabular}{lrrrc}
\hline Factor & Eigenvalue & Difference & Proportion & Cumulative \\
\hline 1 & 3.56331 & 3.13247 & 0.9788 & 0.9788 \\
2 & 0.43084 & 0.28070 & 0.1183 & 1.0972 \\
3 & 0.15015 & 0.19829 & 0.0412 & 1.1384 \\
4 & -0.04815 & 0.05868 & -0.0132 & 1.1252 \\
5 & -0.10682 & 0.04705 & -0.0293 & 1.0958 \\
6 & -0.15388 & 0.04113 & -0.0423 & 1.0536 \\
7 & -0.19501 & & -0.0536 & 1.0000 \\
\hline Variable & & & & \\
\hline Prayer 5 times/day & Factor 1 & Factor 2 & Factor 3 & Uniqueness \\
Fasting in Ramadan & 0.7178 & 0.3655 & 0.0363 & 0.3499 \\
Obey parents & 0.5793 & 0.4160 & 0.0530 & 0.4885 \\
Clothing & 0.6702 & -0.0856 & 0.1459 & 0.5222 \\
Reading Qur'an & 0.7523 & -0.1814 & 0.1083 & 0.3894 \\
Halal diet & 0.7732 & -0.0582 & -0.2137 & 0.3530 \\
Islamic courses & 0.7316 & -0.2692 & 0.1325 & 0.3748 \\
\hline
\end{tabular}


Regression analysis was used to determine if religious or secular education of children, gender, parental income and education, and degree of engagement in problem behaviors predicted Religious Adherence. These explanatory variables accounted for $28 \%$ of the variance in Religious Adherence $\left(\mathrm{R}^{2}=.28, \mathrm{~F}(11\right.$, $147)=5.27, \mathrm{p}<.001)$. Specifically, religious education and maternal income both positively predicted Religious Adherence in children $(p<.05$; see Table 8). Male children had a Religious Adherence score of .29 lower than female children $(p<.05)$. The total number of problem behaviors negatively predicted Religious Adherence by .27 points. Correlation of total number of problem behaviors showed a positive relationship (more engagement in risk behavior) with being male $(r=.11, p<.01)$, and negative relationships with almost all of the religious behaviors, including prayer 5 times per day $(r=-.08, p<.05)$, obeying parents $(r=-.15, p<.001)$, modest clothing $(r=-.15, p<.001)$, reading Qur'an $(r=-.18, p<.001)$, halal diet $(r=-.23, p<.001)$, and Islamic courses $(r=-.22, p<.001)$. Thus, these correlations were consistent with the regression results, as were the t-tests performed earlier.

TABLE 8. Variables predicting religious adherence

\begin{tabular}{lccc}
\hline & $\mathrm{b}$ & $\mathrm{SE}$ & $p(t)$ \\
\hline Religious Education & .1617632 & .0487563 & .001 \\
Male & -.2987364 & .1371793 & .031 \\
Mother's Income & .0000161 & $6.53 \mathrm{e}-06$ & .015 \\
Total number of problem behaviors & -.2702555 & .0687412 & $<.001$ \\
\hline
\end{tabular}

\section{Discussion}

There are several findings of note from our results. First is the development of a Religious Adherence index. Religious behaviors measured in this study consistently correlated with each other, and Cronbach's alpha and factor analysis results indicated the existence of a strong religiosity scale that fit well with this population. Second is the confirmation that religiosity among this sample mitigated socially problematic behavior. This seems to provide support to the general assertion that maintaining religious principles and behavior is perceived as protective against participating in un-Islamic or problematic behaviors. From the perspective of collective identity formation, this also supports the notion that religious adherence is an important factor signaling resistance to what is perceived to be social pathologies of the larger Thai society. Malay Muslims often differentiate themselves from Siamese Thais, who are perceived to be much more inclined to drink or use drugs, engage in premarital sex, and so on.

Of course, the definition of "un-Islamic" behavior is based on subjective religious values. We do know that some of the behaviors identified in this study 
are generally known to be harmful to human health (smoking, drug abuse), while others are not harmful but may be perceived as such by subjective values systems (homosexuality). Discussion of those issues is beyond this paper. Suffice to say that from the perspective of the community, these risk behaviors are generally considered to be harmful, haram (impermissible) in Islam, or both. Thirdly, our findings indicate support for some of the anecdotal generalities that exist regarding this population. Namely, that Muslim male adolescents are more at risk to engage in some forms of problematic behavior than young female adolescents, and that the females are perceived to be more religiously adherent than the males. We tested these generalities using several methods, all of which consistently pointed toward these conclusions. These findings may have implications for educators, community leaders, and religious figures in the southern provinces who work in these areas. They also suggest that ponok settings may have potential to serve as effective settings for public health interventions against drug, tobacco use, other forms of risk behavior, or promote pro-social development in general among Malay Muslim youth. These findings would thus strengthen an argument that Thai government policy makers should work cooperatively with community leaders and support the ponok in such efforts. The fact that some variables such as higher levels of religious education and maternal income predicted Religious Adherence, are interesting findings that also warrant further study. The finding that females in our study were perceived to have higher Religious Adherence and less engagement in socially problematic behavior seems to reflect an expected cultural role, namely, that females are to be both literal and symbolic preservers of tradition and morality. We can expect this social role to persist for Malay Muslim females, particularly as a symbol of pride and cultural resistance to the larger majority culture. We can see in other societies how questions of religious adherence and expression among Islamic minorities, particularly among women, have become points of conflict (e.g., policies about hijab in France). It will be interesting to observe how expectations of religious adherence among this population may develop, and if they will continue to be perceived as protective against social ills from wider Thai society.

There are limitations to this study that should be noted. First, this was not a random sample of the target population, nor was there a suitable control group. Our sample was a convenience sample drawn from a single community affiliated with a ponok within one of the three southernmost provinces, and should thus not be considered generalizable. Another concern would be with respondent bias in the survey instrument we used. Because our questions were sensitive and personal in nature, there is the likelihood that respondents may not have truthfully answered questions either about religious practices, or engagement in perceived risk behaviors. For example, results indicating a very low existence of homosexual behavior are questionable, and suggest a phenomenon 
of denial among parents or conforming to cultural expectations. Because both religious and social problem behavior were reported by parents, the results are vulnerable to "wishful thinking" among parents who likely desire high adherence to religious behavior and values among their children, and low engagement in perceived antisocial behavior. Of course, it is also likely that children may be deceiving parents or peers about their engagement in some forms of stigmatized behavior. Additionally, it should be noted that there were no effects tested in our regression model. As very little research exists on this particular population or setting, there are no clearly established potential confounders. However, we believe that some potential confounders may be related to home setting (rural vs. urban), size of extended family, and a variety of other social support variables. Thus, some caution should be exercised with interpreting this data, and much space exists for future research to explore additional variables that affect this population.

Despite these considerations, our findings seem to align with anecdotal information we know about this population, and are internally consistent after multiple forms of testing. Our descriptive, correlative, and regression model analyses employed a sufficiently large sample size and showed consistent trends in terms of religious and social problem behavior. This study should help fill the gap in quantitative studies with this minority group. We therefore hope that it will contribute to a much-needed empirical knowledge base about this population, and prompt further research into the nexus between religiosity, perceived social problems, and potential opportunities for improving overall wellbeing and health among Malay Muslim adolescents in southern Thailand, a region experiencing significant turmoil and conflict. We suggest that researchers and policy makers further investigate the potential that ponok have in addressing community concerns, and supporting positive social development among adolescents.

\section{References}

Abu Raiya, H., Pargament, K. I., Mahoney, A., \& Stein, C. (2008). A psychological measure of Islamic religiousness: Development and evidence for reliability and validity. International Journal for the Psychology of Religion,18, 291-315. http://dx.doi. org/10.1080/10508610802229270

Brown, R. A. (2014). Islam in modern Thailand: Faith, philanthropy and politics. London: Routledge. (pp 89-91).

Aphornsuvan, T. (2008). Origins of Malay-Muslim "separatism" in southern Thailand. In Michael Montesano \& Patrick Jory (Eds.), Thai south and Malay north (pp. 91123). Singapore: National University of Singapore Press.

Arphattananon, T. (2011). Education for culturally diverse students in Thailand: The case of Muslim students in the southernmost provinces. The International Journal of Learning, 17, 497-510. 
Asia Foundation (Burke, Adam, Tweedie, Pauline, \& Poocharoen, Ora-orn). (2013). The contested corners of Asia: Subnational conflict and international development assistance: The case of southern Thailand. San Francisco, CA: The Asia Foundation.

Asia Foundation (Klein, J.). (2010). Democracy and conflict in southern Thailand: A survey of the Thai electorate in Yala, Narathiwas, and Pattani. Available at http:// asiafoundation.org/resources/pdfs/TAFThailandSouthernReport2010.pdf

Askew, M. (2008). Thailand's intractable southern war: Policy, insurgency and discourse. Contemporary Southeast Asia, 30, 186-214. http://dx.doi.org/10.1355/ CS30-2B

Askew, M. (2009). Landscapes of fear, horizons of trust: villagers dealing with danger in Thailand's insurgent south. Journal of Southeast Asian Studies,40(1), 59-86. http:// dx.doi.org/10.1017/S0022463409000046

Bajunid, O. F. (1999). The Muslims in Thailand: A review. Southeast Asian Studies, 37, $210-234$.

Barrett, J. P., \& Goldsmith, L. (1976). When is n sufficiently large? The American Statistician, 30(2), 67-70. http://dx.doi.org/10.2307/2683795

Burr, A. (1972). Religious institutional diversity, social structural, and conceptual unity: Islam and Buddhism in a southern Thai coastal fishing village. Journal of the Siam Society, 60(2), 185-186.

Burr, A. (1974). Buddhism, Islam and spirit beliefs and practices and their social correlates in two southern Thai coastal fishing villages (Doctoral dissertation, School of Oriental and African Studies (University of London).

Chongkittavorn, K. (2004). Thailand: International terrorism and the Muslim south. Southeast Asian Affairs, 2004, 267-275. http://dx.doi.org/10.1355/SEAA04R

Cortina, J. M. (1993). What is coefficient alpha? An examination of theory and applications. Journal of Applied Psychology, 78(1), 98. http://dx.doi.org/10.1037/00219010.78.1.98

Croissant, A. (2007). Muslim insurgency, political violence, and democracy in Thailand. Terrorism and Political Violence, 19(1), 1-18. http://dx.doi. org/10.1080/09546550601054485

Cronbach, L. (1951). Coefficient alpha and the internal structure of tests. Psychometrika, 16, 297-334. http://dx.doi.org/10.1007/BF02310555

DeVellis, R. F. (2011). Scale development: Theory and applications (Vol. 26). Thousand Oaks, CA: Sage Publications.

Forbes, A. D. (1982). Thailand's Muslim minorities: Assimilation, secession, or coexistence. Asian Survey, 22, 1056-1073. http://dx.doi.org/10.1525/ as.1982.22.11.01p0424w

Fraser, T. M. (1960). Rusembilan: A Malay fishing village in southern Thailand. Ithaca, NY: Cornell University Press.

Fuller, T. (2012, July 23). A fading Thai drug finds in resurgence in a cocktail. New York Times. Available at http://query.nytimes.com/gst/fullpage.html?res=9E05EFDC10 3EF930A15754C0A9649D8B63

Ghorbani, N., Watson, P. J., Ghramaleki, A. F., Morris, R. J., \& Hood, Jr, R. W. (2000). Muslim attitudes towards religion scale: Factors, validity and complexity of relationships with mental health in Iran. Mental Health, Religion \& Culture, 3(2), 125-132. http://dx.doi.org/10.1080/713685603

Hack, K. (2009). The Malayan Emergency as counter-insurgency paradigm. The Journal of Strategic Studies, 32, 383-414. http://dx.doi.org/10.1080/01402390902928180 
Health Systems Management Institute of Southern Thailand. (2014). List of ponok schools. Available at http://hsmi.psu.ac.th/school/province/

Horstmann, A. (2007). The inculturation of a transnational Islamic missionary movement: Tablighi Jamaat al-Dawa and Muslim society in Southern Thailand. Sojourn: Journal of Social Issues in Southeast Asia, 22(1), 107-130. http://dx.doi. org/10.1355/SJ22-1E

Hussey, A. (1993). Rapid industrialization in Thailand 1986-1991. Geographical Review, 83(1), 14-28. http://dx.doi.org/10.2307/215377

Jana-Masri, A., \& Priester, P. E. (2007). The development and validation of a Qur'an-based instrument to assess Islamic religiosity: the Religiosity of Islam Scale. Journal of Muslim Mental Health, 2(2), 177-188. http://dx.doi. org/10.1080/15564900701624436

Ji, C. H. C., \& Ibrahim, Y. (2007). Islamic doctrinal orthodoxy and religious orientations: Scale development and validation. International Journal for the Psychology of Religion, 17, 189-208. http://dx.doi.org/10.1080/10508610701402192

Jitpiromrsi, S., \& McCargo, D. (2008). A Ministry for the south: New governance proposals for Thailand's southern region. Contemporary Southeast Asia: A Journal of International and Strategic Affairs, 30, 403-428. http://dx.doi.org/10.1355/CS303C

Jitpiromsri, S., \& Sobhonvasu, P. (2007). Unpacking Thailand's southern conflict: The poverty of structural explanations. In Duncan McCargo (Ed.), Rethinking Thailand's southern violence (pp. 89-111). Singapore: NUS Press.

Johnson, J.. (2010, Feb. 18). Drugs and disaffection in southern Thailand. Asia times Online. Available at http://www.atimes.com/atimes/Southeast_Asia/LB18Ae03. html

Joll, C. M. (2011). Muslim merit-making in Thailand's far-south. Dordrecht, Netherlands: Springer.

Jones, G. W. (1994). Marriage and divorce in Islamic South-East Asia. Kuala Lumpur, Malaysia: Oxford University Press. (p 5).

Jory, P. (2007). From Melayu Patani to Thai Muslim: The spectre of ethnic identity in southern Thailand. South East Asia Research, 15, 255-279. http://dx.doi. org/10.5367/000000007781509535

Jory, P. (2008). Luang Pho Thuat and the integration of Patani. In Michael Montesano \& Patrick Jory (Eds.), Thai South and Malay North (pp. 292-303). Singapore: National University of Singapore Press.

Koch, M. L. (1977). Patani and the Development of a Thai State. Journal of the Malaysian Branch of the Royal Asiatic Society, 50(2), 69-88.

Krauss, S. E., Hamzah, A. H., Juhari, R., \& Jamaliah, A. (2005). The Muslim ReligiosityPersonality Inventory (MRPI): Towards understanding differences in the Islamic religiosity among the Malaysian youth. Pertanika Journal of Social Sciences \& Humanities, 13(2), 173-186.

Krauss, S. E., Hamzah, A. H., Suandi, T., Noah, S. M., Juhari, R., Manap, J. H., et al. (2006). Exploring regional differences in religiosity among Muslim youth in Malaysia. Review of religious research, 47, 238-252.

Le Roux, P. (1998). To be or not to be: The cultural identity of the Jawi (Thailand). Asian Folklore Studies, 57(2), 223-255. http://dx.doi.org/10.2307/1178753

Liow, J. C. (2004). The security situation in southern Thailand: Toward an understanding of domestic and international dimensions. Studies in Conflict and Terrorism, 27, 531-548. http://dx.doi.org/10.1080/10576100490513701 
Liow, J. C. (2010). Religious education and reformist Islam in Thailand's southern border provinces: The roles of Haji Sulong Abdul Kadir and Ismail Lutfi Japakiya. Journal of Islamic Studies, 21(1), 29-58. http://dx.doi.org/10.1093/jis/etp026

Liow, J. C. (2009). Islam, education and reform in Southern Thailand: Tradition and transformation. Singapore: Institute of Southeast Asian Studies.

LukmanThaib, B. C. P. (2013). Regional cooperation: Malay world and the formation of ASEAN community. Global Journal of Human-Social Science Research, 13(2), 1-9.

Madmarn, Hasan. (2009). The strategy of Islamic education in southern Thailand: The Kitab Jawi and Islamic heritage. Journal of Sophia Asian Studies, 27, 37-49.

Madmarn, H. (2003). Secular education, values and development in the context of Islam in Thailand: An outlook on Muslim attitudes toward Thai educational policy. In Syed Farid Alatas, Lim Teck Ghee \& Kazuhide, K. (Eds.), Asian Interfaith Dialogue: Perspectives on Religion, Education and Social Cohesion (pp. 66-77). Singapore: Centre for Research on Islamic and Malay Affairs \& The World Bank.

Marddent, A. (2007a). Gendering piety of Muslim women in Thailand. Silapatsamnuk, 7(19), 37-43.

Marddent, A. (2007b). Sexual culture among young migrant Muslims in Bangkok. Bangkok: Silkworm Books.

McCargo, D. (2006). Thaksin and the resurgence of violence in the Thai South: Network monarchy strikes back? Critical Asian Studies, 38(1), 39-71. http://dx.doi. org/10.1080/14672710600556429

McCargo, D. (2008). Tearing apart the land. New York: Cornell University Press.

Minitab (n.d.). Multiple regression [White paper]. Retrieved August 19, 2015 from: http://support.minitab.com/en-us/minitab/17/Assistant_Multiple_Regression. pdf

Mokhlis, S. (2009). Relevancy and measurement of religiosity in consumer behavior research. International Business Research, 2(3), 75-84. http://dx.doi.org/10.5539/ ibr.v2n3p75

Mutalib, H. (1990). Islamic revivalism in ASEAN states: Political implications. Asian Survey, 30, 877-891. http://dx.doi.org/10.2307/2644527

Nilsen, M. (2012). Negotiating Thainess: Religious and national identities in Thailand's southern conflict. Lund, Sweden: Lund University Department of History of Religions.

Office of Cultural Affairs of Yala. (2009). Population of Yala by Religion, 2009. Available at http://www.yala.go.th/webyala/SiteMap/Region.html

Phananiramai, M. Population changes and economic development in Thailand: Their implications on women's status. TDRI Quarterly Review, 12(3), 15-26.

Pathmanand, U. (2006). Thaksin's Achilles' heel: The failure of hawkish approaches in the Thai south. Critical Asian studies, 38(1), 73-93. http://dx.doi. org/10.1080/14672710600556452

Peterson, R. A. (1994). A meta-analysis of Cronbach's coefficient alpha. Journal of Consumer Research, 21, 381-391. http://dx.doi.org/10.1086/209405

Prachuabmoh, C. (1980). The role of women in maintaining ethnic identity and boundaries: A case study of Thai-Muslim. Ph. D. dissertation. University of Hawaii.

Puaksom, D. (2008). Of a lesser brilliance: Patani historiography in contention. In Michael Montesano \& Patrick Jory (Eds.), Thai South and Malay North (pp. 71-90). Singapore: National University of Singapore Press.

Putthongchai, S. (2013). What is it like to be Muslim in Thailand? A case study of Thai- 
land through Muslim professionals' perspectives (Unpublished doctoral dissertation). University of Exeter, Exeter, United Kingdom.

Reid, A. (2008). A plural peninsula. In Michael Montesano \& Patrick Jory (Eds.), Thai South and Malay North (pp. 27-38). Singapore: National University of Singapore Press.

Rogers, W. M., Schmitt, N., \& Mullins, M. E. (2002). Correction for unreliability of multifactor

measures: Comparison of alpha and parallel forms approaches. Organizational Research

Methods, 5(2), 184- 199. http://dx.doi.org/10.1177/1094428102005002004

Saleh, R. (2009). "New" relations: Buddhists and Muslims in the three southernmost provinces. In C. Sathan-Anand (Ed.), Imagined land? The state and southern violence in Thailand (pp. 145-164). Tokyo, Japan: Sanrei Printing Co.

Schmitt, N. (1996). Uses and abuses of coefficient alpha. Psychological Assessment, 8, 350-353. http://dx.doi.org/10.1037/1040-3590.8.4.350

Scupin, R. (1980). The politics of Islamic reformism in Thailand. Asian Survey, 20, 1223-1235. http://dx.doi.org/10.2307/2643628

Scupin, R. (1987). Interpreting Islamic movements in Thailand. Crossroads: An Interdisciplinary Journal of Southeast Asian Studies, 3(2/3), 78-93.

Smith, H. E. (1973). The Thai family: Nuclear or extended. Journal of Marriage and the Family, 35(1), 136-141. http://dx.doi.org/10.2307/351107

Suhail, K., \& Chaudhry, H. R. (2004). Predictors of subjective wellbeing in an Eastern Muslim culture. Journal of Social and Clinical Psychology, 23, 359-376. http:// dx.doi.org/10.1521/jscp.23.3.359.35451

Suhrke, A. (1970). The Thai Muslims: Some aspects of minority integration. Pacific Affairs, 43, 531-547. http://dx.doi.org/10.2307/2754903

Tan-Mullins, M. (2007). Voices from Pattani: Fears, suspicion, and confusion. In Duncan McCargo (Ed.), Rethinking Thailand's southern violence (pp. 137-144). Singapore: National University of Singapore Press.

Tavakol, M., \& Dennick, R. (2011). Making sense of Cronbach's alpha. International Journal of Medical Education, 2, 53-55. http://dx.doi.org/10.5116/ijme.4dfb.8dfd

Thai National Statistics Office, Ministry of Information and Communication Technology. (2000). Table 3. Population by religion, sex, area and region. Available at http://web.nso.go.th/eng/en/pop2000/table/eadv_tab3.pdf

Thai National Statistical Office, (2014). The household socio-economic survey: Average monthly income per household, 1996-2013. Available at http://service.nso.go.th/ nso/web/statseries/statseries11.html

Thai PBS. (2015, Jan. 5). Southern violence claims almost 4,000 people in 11 years. Available at http://englishnews.thaipbs.or.th/southern-violence-claims-almost4000-people-11-years

Tiliouine, H., Cummins, R. A., \& Davern, M. (2009). Islamic religiosity, subjective wellbeing, and health. Mental health, religion \& culture, 12(1), 55-74. http://dx.doi. org/10.1080/13674670802118099

Tsuneda, M. (2009). Navigating life on the border: Gender, migration, and identity in Malay Muslim communities in southern Thailand. Doctoral Dissertation (University of Wisconsin-Madison).

UNICEF. (2004). Children and young people in Thailand's southernmost provinces: UNICEF situation analysis. Available at http://www.unicef.org/thailand/ArtSouth.pdf 
Vichit-Vadakan, J. (1994). Women and the family in Thailand in the midst of social change. Law \& Society Review, 28, 515-524. http://dx.doi.org/10.2307/3054071

Virunha, C. (2008). Historical perceptions of local identity in the Upper Peninsula. In Michael Montesano \& Patrick Jory (Eds.), Thai South and Malay North (pp. 39-70). Singapore: National University of Singapore Press.

Winzeler, R. L. (1985). Ethnic relations in Kelantan: A study of the Chinese and Thai as ethnic minorities in a Malay state. Singapore: Oxford University Press.

Yegar, M. (2002). Between integration and secession: The Muslim communities of the southern Philippines, southern Thailand, and western Burma/Myanmar. Lanham, MD: Lexington Books. (pp 73-82).

Yong, K. H. (2012). There are ponoks, and there are ponoks: Traditional religious boarding schools in Thailand's far-south. Advances in Anthropology, 2(3), 161-168. http://dx.doi.org/10.4236/aa.2012.23019

Yusuf, I. (2009). The south Thailand conflict and the Muslim ummah. In C. SathanAnand (Ed.), Imagined land? The state and southern violence in Thailand (pp. 207228). Tokyo, Japan: Sanrei Printing Co. 